\title{
ARTICLE
}

\section{Physiological responses of the red rocky crab Cancer antennarius exposed to different concentrations of copper sulfate}

Respuestas fisiológicas en el cangrejo de roca Cancer antennarius expuesto a diferentes concentraciones de sulfato de cobre

\author{
Linda Lara Jacobo ${ }^{1}$, Fernando Díaz ${ }^{1}$, Ana Denisse Re ${ }^{1 *}$, Clara E. \\ Galindo-Sanchez ${ }^{2}$, Ana Lorena Sanchez-Lizarraga ${ }^{1}$, \\ Luis Antonio Nuñez-Moreno ${ }^{1}$ and \\ Dalia Moreno-Sierra ${ }^{1}$
}

\begin{abstract}
${ }^{1}$ Laboratorio de Ecofisiología de Organismos Acuáticos, Departamento de Biotecnología Marina, Centro de Investigación Científica y de Educación Superior de Ensenada, Carretera Ensenada-Tijuana \# 3918, Baja California, Ensenada B.C., México. *denisre@ cicese.mx ${ }^{2}$ Laboratorio de Genómica Funcional de Organismos Marinos, Departamento de Biotecnología Marina, Centro de Investigación Científica y de Educación Superior de Ensenada, Carretera Ensenada-Tijuana \# 3918, Baja California, Ensenada B.C., México

Resumen.- Se evaluaron en el cangrejo de roca Cancer antennarius las respuestas fisiológicas, metabólicas y hematológicas a diferentes concentraciones de sulfato de cobre $\left(0,5,1,0,1,5,2,0 \mathrm{mg} \mathrm{L}^{-1}\right)$. Las respuestas a determinar fueron: dosis letal media, capacidad osmorreguladora, consumo de oxígeno, excreción de amonio, relación atómica O:N, glucosa, el CTH y la concentración de hemocianina. En cuanto a la dosis letal media $\left(\mathrm{LD}_{50}\right)$ se determinó que la concentración fue de $1,6 \mathrm{mg} \mathrm{L}^{-1}$ de sulfato de cobre. El patrón observado en la mayoría de las respuestas medidas fue un aumento directamente proporcional a la concentración de sulfato de cobre; a excepción de la capacidad osmorreguladora, en la que el patrón de osmorregulación, de ser típicamente isosmótico en condiciones normales, se modificó a hiposmótico. En la relación atómica O:N se observó una disminución en los valores debido a cambios en sustrato metabólico como un resultado del estrés causado por la exposición al sulfato de cobre.
\end{abstract}

Palabras clave: Consumo de oxígeno, excreción de amonio, sulfato de cobre, Cancer antennarius

\begin{abstract}
In this study we evaluated physiological, metabolic and hematological responses for the crab Cancer antennarius to different copper sulfate concentrations $\left(0.5,1.0,1.5,2.0 \mathrm{mg} \mathrm{L}^{-1}\right)$. The evaluated responses were: the median lethal dose, osmoregulatory capacity, oxygen consumption, ammonium excretion, atomic relation $\mathrm{O}: \mathrm{N}$, glucose, THC and hemocyanin concentration. The median lethal dose $\left(\mathrm{LD}_{50}\right)$ we found was $1.6 \mathrm{mg} \mathrm{L}^{-1}$ of copper sulfate. The pattern followed on most of the observed responses was an increase directly proportional to the amount of copper sulfate concentration, except for osmoregulatory capacity where the osmoregulation pattern, usually isosmotic in normal conditions, was modified to hyposmotic. In the atomic relation $\mathrm{O}: \mathrm{N}$ we observed a decrease in values due to changes in metabolic substrate as a result of stress caused by exposure to copper sulfate.
\end{abstract}

Key words: Oxygen consumption, ammonia excretion, copper sulfate, Cancer antennarius

\section{INTRODUCTION}

Copper is an essential micronutrient required by all living organisms for a variety of physiological and biochemical processes. In crustaceans, copper is also part of the respiratory pigment, called hemocyanin, which participates in the transport of oxygen. Although copper is an essential element to aquatic organisms, it can be potentially toxic when its amount is above the usual standards (Gutierrez-Galindo et al. 1994, Martins et al. 2011). Even though there are important natural copper sources, multiple human activities have considerably increased the input of this metal in estuarine and marine environments around the world (Niencheski et al. 2006).
Organisms assimilate copper according to the proportion of this metal in the water; these assimilations occur throughout epithelia surfaces, where ions are also absorbed and excreted (Santore et al. 2001). Copper competes with other cations in order to bind with the uptake sites such as the gills, and once it is absorbed in various tissues it can become toxic (Engel 1993, Santore et al. 2001, Abolude 2009, Frias-Espericueta et al. 2011).

Different studies have shown that some metals such as copper have the ability to produce reactive oxygen species, resulting in lipid peroxidation, DNA damage, changes in sulfide groups and 
altered calcium homeostasis (Stohs \& Bagchi 1994, Barata et al. 2005). Sensitivity to copper can also depend on the homeostatic regulation of its uptake, storage and excretion (Depledge \& Rainbow 1990). The metal concentrations were monitored since the 80's when it was observed that an increase of metals in the sea had begun due anthropogenic activities.

Buck et al. (2007) made a study in San Francisco Bay (North Pacific) where they found that the copper has reduced their concentrations of free hydrated copper ion, and the toxic species of copper, to below 1013M. However these copperbinding organic ligands, $\mathrm{Cu}_{2}+$ would exist at levels toxic to most microorganisms living within the Bay.

In recent years there have been comparisons of these measurements and it has been determined that these metals are principally copper, cadmium, and zinc in the North Occident of Mexico (Gutierrez-Galindo et al. 1997, Frias-Espericueta et al. 2011).

Responses to stressors have traditionally been observed at the population, community or ecosystem level. Effects however are also manifested at the organismic level by impairing molecular, cellular and physiological functions (Hebel et al. 1997). Different histological, physiological, and molecular toxicants actions induce stress referred as biomarkers; they have been suggested and used to predict the stress effects and the animal response (Wedderburn et al. 1998, Sokolova \& Lanning 2008). Osmoregulation maintaining osmotic homeostasis can be considered as a possible marker for crustaceans (Lignot $e t$ al. 2000). Osmoregulation, one of the most important regulatory functions an aquatic animal has to perform, has been extensively studied in many crustaceans that effectively osmoregulate, either as hyper-isosmoregulators or hyper-hypo-regulators; this occurring in marine, brackish and freshwater conditions (Mantel \& Farmer 1983, Péqueux 1995).

Monitoring the crustacean physiological condition during the process of osmoregulation could therefore have a potential use as a biomarker in coastal waters, estuaries and lagoons. In particular, osmoregulatory capacity (OC) can be used as a reliable biomarker to monitor the physiological condition and the effect of stressors in crustaceans (Lignot et al. 2000).

The metabolic rate measurement has been used as a tool to determine the impact that several environmental factors can have in the organism, such as temperature, salinity or exposure to pollutants. This allows us to determine the energetic costs that these combinations have in the organism (Altinok \& Grizzle 2003, Manush et al. 2004, Brougher et al. 2005, Sokolova \& Lanning 2008). Oxygen consumption $\left(\mathrm{VO}_{2}\right)$ is intimately associated with the metabolic work and the energy flow that an organism can use for homeostatic process. Hemocyanin respiratory pigment is also a protein responsible of transporting oxygen and carbon dioxide through the hemolymph that constitutes 60 to $95 \%$ of the total plasma protein-, and an efficient physiological indicator of stress conditions.

The ammonium excretion rate has been used to evaluate the effect of various environmental factors and contaminants in crustacean physiology (Jiang et al. 2000). Ammonium represents 40 to $90 \%$ of the total nitrogen excreted by the crustaceans and is continuously released through the branchial epithelium (Regnault 1987).

Cancer antennarius (Stimpson, 1856) is a crustacean that its defense mechanism is based in the defense response of the hemocytes. These are incorporated in the hemolymph and they release molecules such as the serum prophenoloxidase system. Regarding crustaceans their hemocyte classification is based on morphological, functional, ultrastructural characteristics and the presence or absence of granules. Generally they are represented in 3 groups: hyalinocytes, semi granulocytes and granulocytes (Vargas-Albores et al. 1993).

Physiological studies have been done in other economically important crustaceans such as white shrimp Litopenaeus vannamei (Sanchez et al. 2001) or the crab Cancer magister and Callinectes sapidus (Hutcheson 1974 in Sokolova \& Lanning 2008) in Cd; however, in red rocky crab $C$. antennarius there has been only a study on larval nutrition ( Re \& Bückle 1983) and in relation to thermal biology (PadillaRamirez et al. 2015). Therefore, there are not available physiological studies that measure metabolic responses, glucose, lactate, total protein, cholesterol, triglycerides, lipids, hemocyanin, hemocytes and respiratory burst.

Cancer antennarius is an important crab in Baja California in the north and southern part of the peninsula; its distribution range extends from northern California up to Alaska (MacGinitie 1935, Re \& Bückle 1983). It lives in rocky shores, sandy substrates, semi buried under stones, in bays and estuaries. Its sexual maturity is reached at 2 years of age and it can be 60-80 mm wide (Carroll \& Win 1989). The commercial importance of rock crab lays in its chelae, which is similar to that of the Dungeness crab Cancer magister, Cancer antennarius that are fished both commercially and recreationally. The industry is smaller compared to the fishery of Cancer magister, and it is mostly captured in California (Carroll \& Win 1989).

The aim of this study is to evaluate the effect that an injection of copper sulfate can have in the osmoregulatory capacity, oxygen consumption, ammonium excretion, glucose and total hemocyte count and hemocyanin concentration in $C$. antennarius adults. 


\section{Materials AND METHODS}

Cancer antennarius crabs were obtained from Ejido Erendira, municipality of Ensenada, Baja California, Mexico $\left(31^{\circ} 16^{\prime} 19.52^{\prime}\right.$ N, $\left.116^{\circ} 23^{\prime} 46.46^{\prime \prime} \mathrm{W}\right)$ during the summer season in the weight range of 200-300 g wet weight (w.w.). In the local area distribution of red crab in Baja California, temperatures in an annual cycle vary between $15^{\circ} \mathrm{C}$ in winter and $20.5^{\circ} \mathrm{C}$ in summer (Center for Atmospheric Sciences 2013).

These animals were acclimated one week to laboratory temperature conditions of $20^{\circ} \mathrm{C}$ in a closed system with water replacement; they were also fed daily with chunky fresh fish. They were individually distributed in plastic baskets where each one of these contained 20 organisms. In total, 250 adult crabs were used. They were randomly selected before each experiment. 50 crabs were used as experimental controls, 25 of these were injected with saline solution $500 \mu \mathrm{L}$, and this group was called 'saline control'. Another group of 25 was considered as the controlled organisms: they were not injected. Both groups control and saline control- were exposed to the same experimental procedure. To determine the lethal dose $\left(\mathrm{LD}_{50}\right) 10$ crabs (n total $=40$ ) were injected with each of the concentrations of copper sulfate $(0.0,0.5,1.0,1.5$, and 2.0 $\mathrm{mg} \mathrm{L}^{-1}$ ) (Fermont 63362) (Chemical Products Monterrey, Mexico, CAS7758-99-8), and survival was monitored for 96 $\mathrm{h}$. The median lethal dose was determined by the Probit method.

Different copper sulfate concentrations were prepared for each experiment, and the number of experimental crabs was 25 for each concentration where (control C 0.0, CS control saline and $0.5,1.0,1.5$, and $2.0 \mathrm{mg} \mathrm{L}^{-1}$ ) of copper sulfate. All groups of crabs were injected with $500 \mathrm{iL}$ of the solution at the right side of their fifth pereipod.

Hemolymph was extracted from 25 crabs for each experimental condition $\left(0.5,1.0,1.5\right.$ and $\left.2.0 \mathrm{mg} \mathrm{L}^{-1}\right)$, including the controlled organisms (C, CS). This was carried out by a hypodermic syringe with a solution of $1 \mathrm{ml}$ heparin as anticoagulant. This syringe was inserted in the crab's coxa and then $300 \mu \mathrm{L}$ of hemolymph were extracted with an automatic pipette. After obtaining the hemolymph samples, these were placed on a sheet of parafilm, which was kept cold on a plate to $4^{\circ} \mathrm{C}$. The hemolymph sample was divided into fractions of $50 \mu \mathrm{L}$ for posterior analysis, and then it was diluted (1:1) with the solution of Vargas-Albores et al. (1993) for an analysis of the total count of hemocyte; $50 \mu \mathrm{L}$ were diluted in Alsever solution for analysis glucose quantification.

To measure hemolymph osmolality $10 \mu \mathrm{L}$ were taken. Hemolymph osmolality and of seawater were determined by the Wescor 550 vapor osmometer, and the data was expressed in $\mathrm{mmol} \mathrm{kg}^{-1}$. To assess the ability of the organisms to maintain osmoregulatory capacity from each treatment, this was calculated from the following formula: Osmoregulatory capacity $\mathrm{OC}=$ internal media concentration - concentration of the external medium (Lignot et al. 2000).

Oxygen consumption routine rate (OCRR, $\mathrm{mg} \mathrm{O}_{2} \mathrm{~h}^{-1} \mathrm{~kg}^{\mathrm{WW}-1}$ ) of the experimental organisms was quantified for each different experimental condition using a semi-open respirometer system (Díaz et al. 2007). The oxygen concentration was measured by an oxymeter (YSI 52B) with a polarographic sensor, which helped avoid contact with air. We also took an initial sample of oxygen before closing the respirometric chambers. Thirteen crabs were placed individually in respirometric chambers of $3000 \mathrm{~mL}$, with an empty respirometric chamber to measure oxygen consumption by microorganisms present in the water (control). Water temperature was maintained at $20 \pm 1^{\circ} \mathrm{C}$ (Padilla-Ramirez et al. 2015).

Respirometric chambers remained closed for $40 \mathrm{~min}$, as Thurberg et al. (1973). The respirometric chambers consisted of a complete airtight container that had a valve that allowed the aerated water to inlet and also to outlet water with a low oxygen concentration. After this time the final measurement was made and the aerated water flow was reopened to allow water exchange in the chambers. Measuring of OCRR exposed to different copper concentrations was calculated by the following equation according to Cerezo-Valverde et al. (2006) and Zheng et al. (2008):

$$
\text { OCRR }=(\mathrm{Ct}-\mathrm{Co}) \mathrm{V} /(\mathrm{WW} \times \mathrm{T}),
$$

where $\mathrm{Ct}$ and $\mathrm{Co}$ represent the variation regarding the oxygen content $\left(\mathrm{mg} \mathrm{O}_{2} \mathrm{~h}^{-1} \mathrm{~kg}^{\mathrm{WW}-1}\right), \mathrm{V}$ is the volume of the respirometric chamber before and after measuring the tests; $w w$ was the wet weight of C. antennarius $(\mathrm{g})$ and $\mathrm{T}(\mathrm{h})$ the time duration.

To determine the ammonium excretion rate (AER) we followed the procedure described above for oxygen consumption. It took a $10 \mathrm{~mL}$ water sample from each chamber to measure ammonia concentration using the method of phenol indo blue (Rodier 1981 modificated by Medina-Romo 2015). The tubes were covered with parafilm and left to incubate for one hour. After the reaction, the samples were read in a spectrophotometer at an absorbance of $640 \mathrm{~nm}$ (DR/4000U Spectrophotometer). Ammonia concentration was determined by a calibration curve, with ammonium chloride J.T. Baker 0660-01 (Phillisbur, N.J., USA). The calculation for AER was carried out with the following equation:

$$
\mathrm{AER}=\left(\mathrm{Ct}^{\prime}-\mathrm{Co}\right)^{\prime} \mathrm{V} /(\mathrm{WW} \times \mathrm{T})
$$

where $\mathrm{Ct}^{\prime}$ and $\mathrm{Co}$ ' are the change in ammonia excretion initial and final in $\mathrm{mg} \mathrm{NH}_{4}^{+} \mathrm{h}^{-1} \mathrm{~kg}^{\mathrm{WW}-1}, \mathrm{~V}$ is the bottle volume control 
before and after the tests, ww was the wet weight of $C$. antennarius $(\mathrm{g})$ and $\mathrm{T}(\mathrm{h})$ the duration time.

The atomic relation oxygen:nitrogen $(\mathrm{O}: \mathrm{N})$ was calculated using the values obtained from crabs oxygen consumption and nitrogen excretion when exposed to different concentrations of copper sulfate. The calculation was made as follows:

$$
\begin{aligned}
& \mathrm{O}: \mathrm{N}=\text { atomic weight }\left(\mathrm{NH}_{4}^{+}\right) / \\
& \text {atomic weight }\left(\mathrm{O}_{2}\right) *\left[\mathrm{QO}_{2}\right] /[\mathrm{NH} 4+]
\end{aligned}
$$

where $\mathrm{QO}_{2}$ is the oxygen consumption and $\mathrm{NH}_{4}+$ is the total ammonia excreted by organisms.

The samples of hemolymph were centrifuged at $800 \mathrm{~g}$ for 3 min at $4^{\circ} \mathrm{C}$, and the supernatant was removed for glucose quantification, using the kit called 'Scientific Pointe, Inc.' (with a sensitivity of $1 \mathrm{mg} \mathrm{dL}^{-1}$ ). These samples were read at $500 \mathrm{~nm}$ on a Hatch spectrophotometer; the glucose concentration was calculated according to the fabricant instructions.

Quantifying hemocyanin was obtained immediately after the extraction, samples were taken from $10 \mu \mathrm{L}$ of hemolymph without heparin from organisms from all experimental conditions, and the samples were diluted with $990 \mu \mathrm{L}$ of distilled water in the cells of the spectrophotometer and read at $280 \mathrm{~nm}$ (Engel \& Brouwer 1987). Hemocyanin concentration was determined by calculation based on a subunit of 74,000 Da for crustaceans (Hagerman 1986).

The total hemocyte count was carried out with an automated cell counter device TC10 Gemstar USA BIORAD in which hemolymph was introduced with the anticoagulant according to Vargas Albores et al. (1993) and placed in the appropriate counting chamber for reading. To perform the total hemocyte count (THC), $10 \mu \mathrm{L}$ of hemolymph from each control and experimental group were placed in a TC10. Each plate was calculated with a dual chamber and then these were inserted in a TC10 cell counter for the hemocytes sequential counting.

The physiological response data obtained by the crab exposure to the copper sulfate were processed through an exploratory data analysis (Tukey 1977). A one-way analysis of variance was used following the tests to show the normality (Shapiro-Wilk test) and homoscedasticity (Bartlett test) of the data. A Kruskal-Wallis test was used to determine whether there were differences in the oxygen consumption OCRR, ammonium excretion rate $\mathrm{AER}$, atomic relation $\mathrm{O}: \mathrm{N}$, glucose concentration, hemocyanin, and THC between the different concentration of copper sulfate. The effect of the exposition to copper sulfate on of the crab was then analyzed using Sigma Stat version 3.1 and plotted with Sigma Plot version 12.

\section{RESULTS}

We found that the $\mathrm{LD}_{50}$ was $1.6 \mathrm{mg} \mathrm{L}^{-1}$ of copper sulfate for Cancer antennarius. The control group showed a $100 \%$ survival, whereas those injected with saline solution (concentration of $0.5 \mathrm{mg} \mathrm{L}^{-1)}$ had a $95 \%$ survival. Organisms at a concentration of $1.0 \mathrm{mg} \mathrm{L}^{-1}$ had a survival of $66.6 \%$. Whereas those exposed to $1.5 \mathrm{mg} \mathrm{L}^{-1}$ its survival decreased down to $58.30 \%$. As for the ones with a concentration of $2.0 \mathrm{mg} \mathrm{L}^{-1}$, their survival decreased down to $41.6 \%$ (Fig. 1, Table 1).

In experimental organisms, crabs injected with different copper sulfate concentrations showed an adverse effect in relation to their osmoregulatory capacity (OC). Crabs OC had a range from $-1 \pm 3.08$ to $-3 \pm 3.58$ for the control ones with a copper concentration of $0.5 \mathrm{mg} \mathrm{L}^{-1}$. At a higher concentration the range was $-29 \pm 4.10$ to $-64 \pm 4.11$ (Fig. 2); a change was observed in $C$. antennarius hemolymph regulation pattern, changing from being isosmotic to hyposmotic.

Oxygen consumption routine rate and nitrogen excretion of C. antennarius increased as the copper dose also augmented. The value ranges for the OCRR were $46.06 \pm 9.08$ to $84.00 \pm$ $10.1 \mathrm{mg} \mathrm{O}_{2} \mathrm{~h}^{-1} \mathrm{~kg}^{-1}$; and for the AER from $1.43 \pm 0.21$ to 0.26 $\pm 0.02 \mathrm{mg} \mathrm{NH}^{+}{ }_{4} \mathrm{~h}^{-1} \mathrm{~kg}^{-1}$, being significantly different $(P<0.05)$ (Figs. 3 and 4).

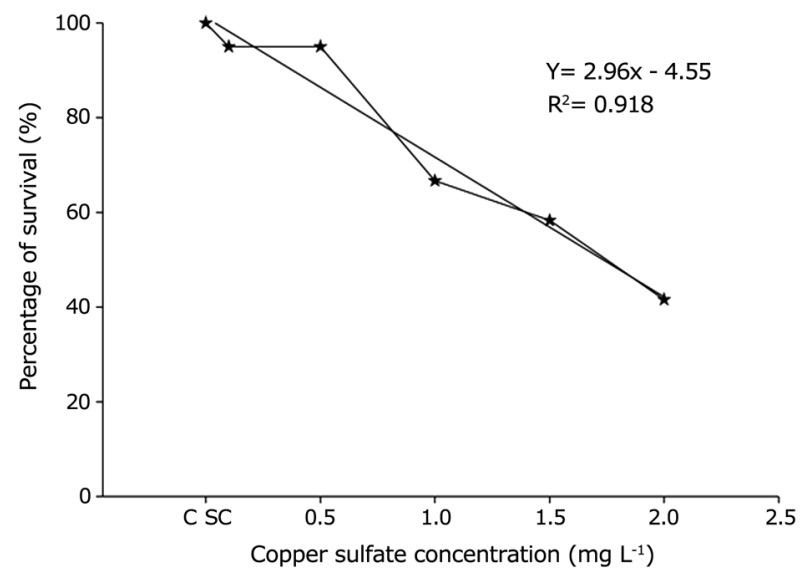

Figure 1. Percentage of survival (\%) of Cancer antennarius exposed to different concentrations of copper sulfate (10 organisms per unit concentration). C control, SC saline control / Porcentaje de supervivencia (\%) de Cancer antennarius expuesto a diferentes concentraciones de sulfato de cobre (10 organismos por concentración). C control, SC control salino 
Table 1. Physiological responses of organisms exposed to different concentrations of copper $0.5 ; 1.0 ; 1.5$, and 2.0 and two controls (C) $\mathbf{0 . 0}$ and saline control (CS) lowercase letters set significance $(\mathbf{P}<\mathbf{0 . 0 0 1}) /$ Respuestas fisiológicas obtenidas de los organismos expuestos a las diferentes concentraciones de cobre 0,$5 ; 1,0 ; 1,5$; y 2,0 y dos controles (C) 0,0 y control salino (CS), las letras minúsculas establecen la significancia $(P<0,001)$

\begin{tabular}{|c|c|c|c|c|c|c|}
\hline \multirow{2}{*}{ Physiological responses } & \multicolumn{6}{|c|}{ Copper sulfate concentrations $\left(\mathrm{mg} \mathrm{L}^{-1}\right)$} \\
\hline & Control ( C ) & Control (CS) & 0.5 & 1.0 & 1.5 & 2.0 \\
\hline $\mathrm{OC}\left(\mathrm{mmol} \mathrm{kg}{ }^{-1}\right)$ & $-1 \pm 3.08^{\mathrm{a}}$ & $-3 \pm 3.93^{\mathrm{a}}$ & $-3 \pm 3.58^{\mathrm{a}}$ & $-29 \pm 4.10^{b}$ & $-57 \pm 5.32^{\mathrm{c}}$ & $-64 \pm 4.11^{c}$ \\
\hline Atomic ratio $\mathrm{O}: \mathrm{N}$ & $54.56 \pm 4.28^{\mathrm{a}}$ & $46.75 \pm 4.61^{\mathrm{a}}$ & $35.45 \pm 3.22^{\mathrm{a}}$ & $26.25 \pm 4.2^{b}$ & $15.50 \pm 3.2^{\mathrm{c}}$ & $11.25 \pm 4.2^{\mathrm{c}}$ \\
\hline OCR $\left(\mathrm{mg} \mathrm{O}_{2} \mathrm{~h}^{-1} \mathrm{~kg}^{-1}\right)$ & $46.06 \pm 9.08^{\mathrm{a}}$ & $47.87 \pm 9.93^{\mathrm{a}}$ & $49.79 \pm 10.58^{\mathrm{a}}$ & $65.36 \pm 9.1^{\mathrm{b}}$ & $74.58 \pm 10.3^{c}$ & $84.00 \pm 10.1^{\mathrm{c}}$ \\
\hline $\operatorname{AER}\left(\mathrm{mg} \mathrm{NH}_{4} \mathrm{~h}^{-1} \mathrm{~kg}^{-1}\right)$ & $0.26 \pm 0.02^{\mathrm{a}}$ & $0.28 \pm 0.018^{\mathrm{a}}$ & $0.31 \pm 0.022^{\mathrm{a}}$ & $1.20 \pm 0.1^{\mathrm{b}}$ & $1.24 \pm 0.08^{\mathrm{c}}$ & $1.43 \pm 0.21^{\mathrm{c}}$ \\
\hline THC $\left(1 \times 10^{6}\right)$ & $3.00 \pm 0.78^{\mathrm{a}}$ & $4.87 \pm 0.71^{\mathrm{a}}$ & $5.68 \pm 0.62^{\mathrm{a}}$ & $6.98 \pm 0.72^{b}$ & $8.28 \pm 0.92^{\mathrm{c}}$ & $9.36 \pm 0.51^{\mathrm{c}}$ \\
\hline Hemocyanin $\left(\mathrm{mg} \mathrm{L}^{-1}\right)$ & $2.50 \pm 0.58^{\mathrm{a}}$ & $2.53 \pm 0.61^{\mathrm{a}}$ & $2.70 \pm 0.62^{\mathrm{a}}$ & $3.7 \pm 0.7^{\mathrm{b}}$ & $4.56 \pm 0.42^{\mathrm{c}}$ & $5.34 \pm 0.51^{\mathrm{c}}$ \\
\hline Glucose $\left(\mathrm{mg} \mathrm{L}^{-1}\right)$ & $25.72 \pm 4.23^{\mathrm{a}}$ & $27.45 \pm 4.61^{\mathrm{a}}$ & $31.24 \pm 3.22^{\mathrm{a}}$ & $44.59 \pm 4.2^{\mathrm{b}}$ & $60.41 \pm 3.22^{\mathrm{c}}$ & $74.63 \pm 4.2^{\mathrm{d}}$ \\
\hline
\end{tabular}

OC: Osmoregulatory capacity, OCR: Oxygen routine consumption, AER: Ammonium excretion, THC: Total hemocyte count

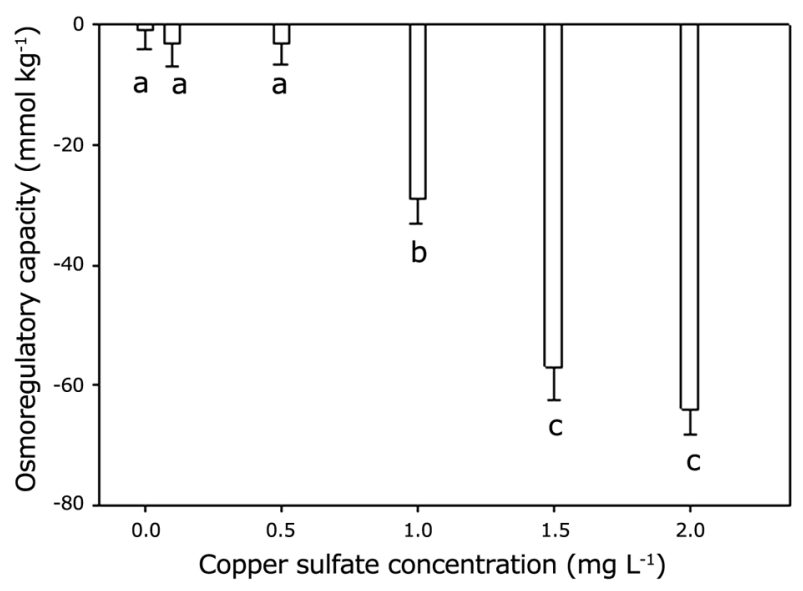

Figure 2. Osmoregulatory capacity $\left(\mathrm{mmol} \mathrm{kg}^{-1}\right)$ of Cancer antennarius exposed to different concentrations of copper sulfate $(25$ organisms per unit concentration. Different letters indicate significant differences between concentrations of copper sulfate $(\alpha=0.05)$. Media \pm SE / Capacidad osmorregulatoria $\left(\mathrm{mmol} \mathrm{kg}^{-1}\right)$ de Cancer antennarius expuesto a diferentes concentraciones de sulfato de cobre 25 organismos por concentración). Diferentes letras indican diferencias significativas entre las concentraciones de sulfato de cobre $(\alpha=0,05)$. Media \pm ES

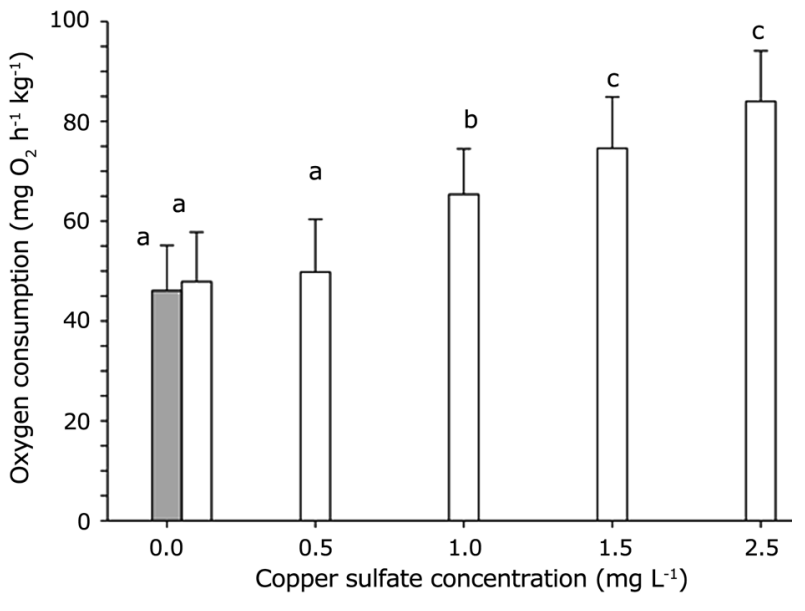

Figure 3. $0 x y g e n$ routine consumption ( $\mathrm{mg} \mathrm{O}_{2} \mathrm{~h}^{-1} \mathrm{~kg}^{-1}$ ) of Cancer antennarius exposed to different concentrations of copper sulfate. Different letters indicate significant differences between concentrations of copper sulfate $(\alpha=0.05)$. Media \pm SE / Consumo de oxígeno de rutina $\left(\mathrm{mg} \mathrm{O}_{2} \mathrm{~h}^{-1} \mathrm{~kg}^{-1}\right)$ de Cancer antennarius expuesto a diferentes concentraciones de sulfato de cobre. Diferentes letras indican diferencias significativas entre las concentraciones de sulfato de cobre $(\alpha=0.05)$. Media \pm ES 


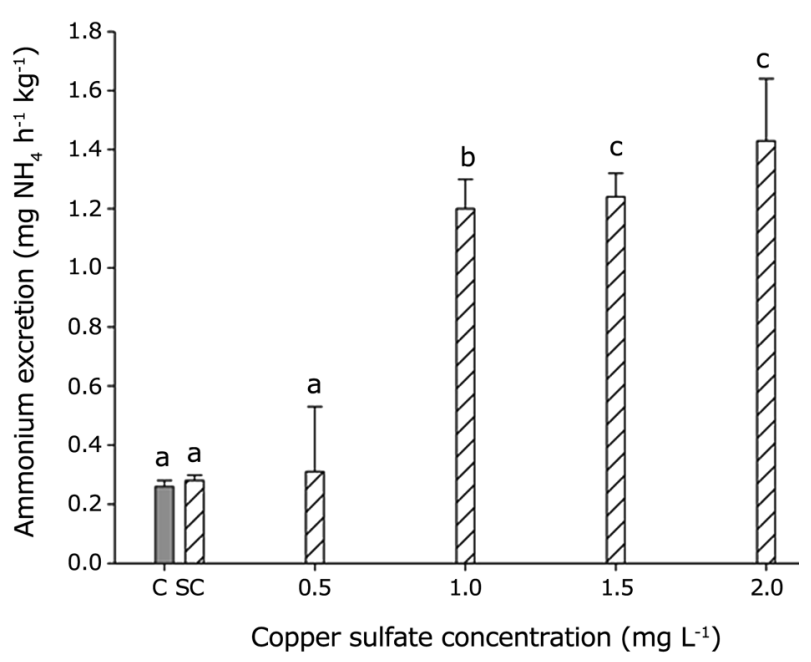

Figure 4. Ammonium excretion $\left(\mathrm{mg} \mathrm{NH}_{4} \mathrm{~h}^{-1} \mathrm{~kg}^{-1}\right)$ of Cancer antennarius exposed to different concentrations of copper sulfate $(25$ organisms per unit concentration). C control, SC saline control. Different letters indicate significant differences between concentrations of copper sulfate $(\alpha=0.05)$. Media $\pm \mathrm{SE} /$ Excreción de amonio $\left(\mathrm{mg} \mathrm{NH}_{4} \mathrm{~h}^{-1} \mathrm{~kg}^{-1}\right)$ de Cancer antennarius expuesto a diferentes concentraciones de sulfato de cobre (25 organismos por concentración). C control, SC control salino. Diferentes letras indican diferencias significativas entre las concentraciones de sulfato de cobre $(\alpha=0,05)$. Media \pm ES

The values of the O:N in each of the different concentrations had an interval of $11.25 \pm 4.2$ to $54.56 \pm 4.28$ indicating a change in the metabolic substrate type used by the crab (Fig. 5).

At the lowest concentration of copper the glucose in hemolymph $\left(25.72 \pm 4.23 \mathrm{mg} \mathrm{L}^{-1}\right)$ was not different for control organisms, crabs in the saline group and those exposed to 0.5 $\mathrm{mg} \mathrm{L}^{-1}$ of $\mathrm{CuSO}_{4}$. Though we did find significant differences when the copper concentration incremented glucose levels increased from $44.59 \pm 4.2$ to $74.63 \pm 4.2(P<0.05)$ (Fig. 6).

The concentration of hemocyanin in the hemolymph of the organisms exposed to copper sulfate had an interval of $2.50 \pm$ 0.58 to $5.34 \pm 0.51 \mathrm{mmol} \mathrm{L}^{-1}$. Controls showed no significant differences $(P>0.05)$ in their levels of hemocyanin compared to saline control organisms. There were no significant differences $(P>0.05)$ between the values of hemocyanin in the crabs at control, saline control conditions, and the concentration of 0.5 $\mathrm{mg} \mathrm{L}^{-1} \mathrm{CuSO}_{4}$. Crabs injected with high concentrations of copper sulphate, did show meaningful differences $(P<0.05)$ in the levels of hemocyanin (Fig. 7).

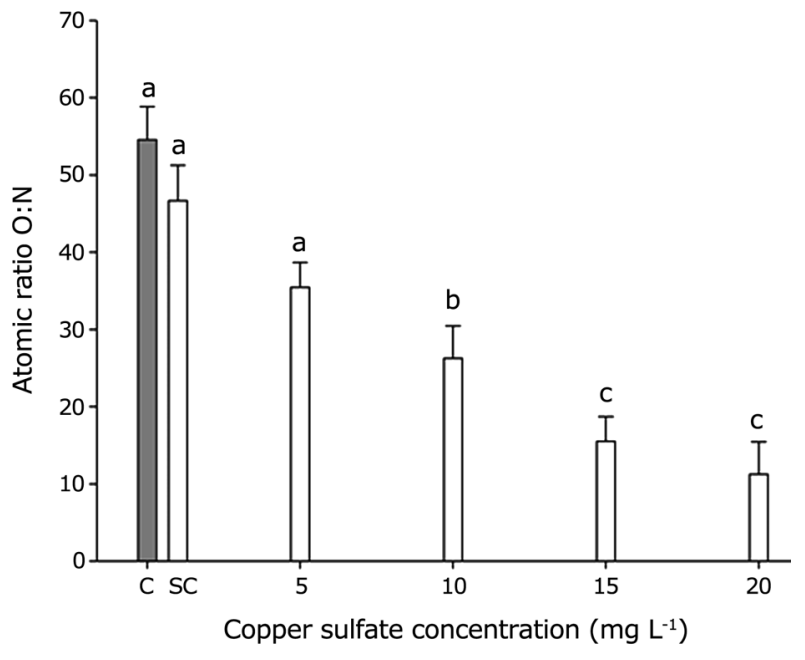

Figure 5. Atomic ratio oxygen:nitrogen $0: \mathrm{N}$ of Cancer antennarius exposed to different concentrations of copper sulfate. C control, SC saline control. Different letters indicate significant differences between concentrations of copper sulfate $(\alpha=0.05)$. Media \pm SE / Relación atómica oxígeno:nitrógeno $\mathrm{O}: \mathrm{N}$ de Cancer antennarius expuesto a diferentes concentraciones de sulfato de cobre. C: control, SC: Control salino. Diferentes letras indican diferencias significativas entre las concentraciones de sulfato de cobre $(\alpha=0,05)$. Media \pm ES

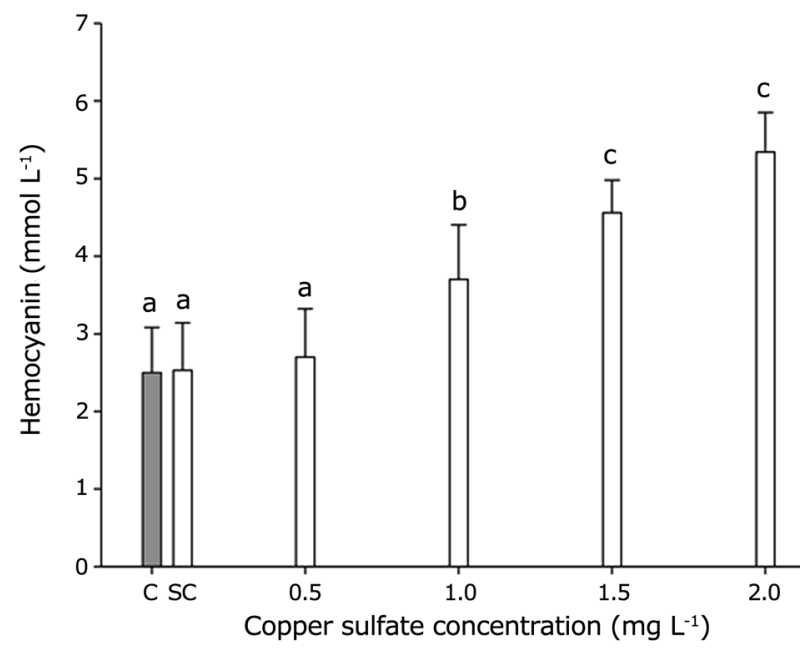

Figure 6. Hemocyanin concentration $\left(\mathrm{mmol} \mathrm{kg}^{-1}\right)$ in hemolymph of Cancer antennarius exposed to different concentrations of copper sulfate. C control, SC saline control. Different letters indicate significant differences between concentrations of copper sulfate $(\alpha=$ 0.05). Media \pm SE / Concentración hemocianina $\left(\mathrm{mmol} \mathrm{kg}^{-1}\right)$ en hemolinfa de Cancer antennarius expuesto a diferentes concentraciones de sulfato de cobre. C control, SC control salino. Diferentes letras indican diferencias significativas entre las concentraciones de sulfato de cobre $(\alpha=0,05)$. Media \pm ES 


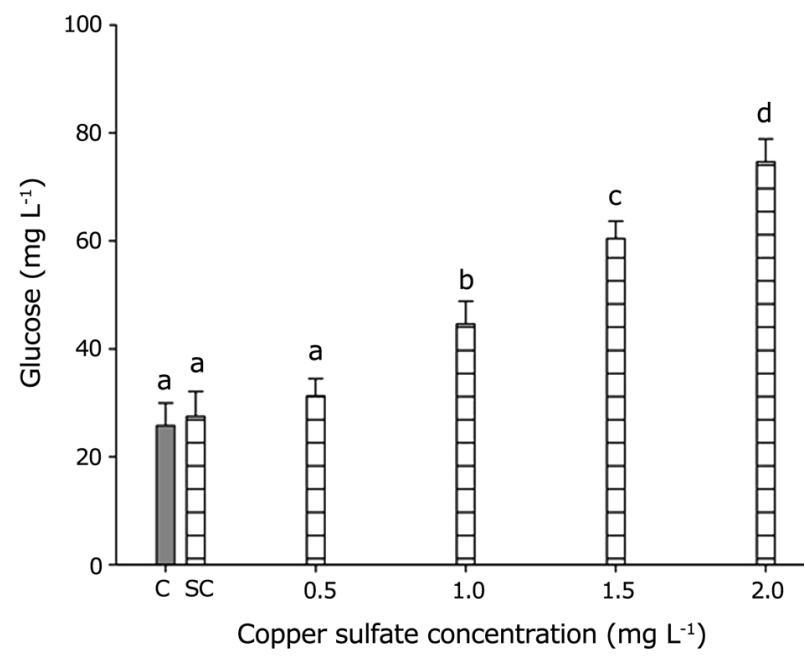

Figure 7. Glucose concentration ( $\mathrm{mg} \mathrm{L}^{-1}$ ) in hemolymph of Cancer antennarius exposed to different concentrations of copper sulfate. $C$ control, SC saline control. Different letters indicate significant differences between concentrations of copper sulfate $(\alpha=0.05)$. M edia \pm SE / Concentración de glucosa $\left(\mathrm{mg} \mathrm{L}^{-1}\right)$ en la hemolinfa de Cancer antennarius expuesto a diferentes concentraciones de sulfato de cobre. C control, SC control salino. Diferentes letras indican diferencias significativas entre las concentraciones de sulfato de cobre $(\alpha=0,05)$. Media \pm ES

As for the total hemocyte count there were not significant differences (THC) between the control, the saline control and the organisms exposed to $0.5 \mathrm{mg} \mathrm{L}^{-1}$ of $\mathrm{CuSO}_{4}$. However, there were significant differences $(P<0.05)$ in the THC $(6.98 \pm 0.72$ to $\left.9.36 \pm 0.511 \times 10^{6}\right)$ at high concentrations of $\mathrm{CuSO}_{4}(\mathrm{Fig} .8)$.

\section{Discussion}

The injection of copper sulfate had major consequences on survival and general physiological performance of Cancer anntenarius. Mendoza-Rodriguez (2009) in Caementarus cryphiops observed the effect of copper sulfate in a concentration of 0.0078 and $0.0126 \mathrm{mg} \mathrm{L}^{-1}$, determining a survival of 10 and $0 \%$, respectively. In the case of the commercial shrimp Artemesia longinaris, a median lethal dose was obtained at $72 \mathrm{~h}$ of $0.212 \mathrm{mg} \mathrm{L}^{-1}$ (Scelzo 1997). For commercial crab Lithodes santolla, Amin \& Comoglio (2010) obtained a median lethal copper concentration of $0.002985 \mathrm{mg} \mathrm{L}^{-1}$ at 96 h. In the shore crab Carcinus maenas, Boitel \& Truchot (1989) they conducted acute toxicity studies with copper obtaining the average lethal concentration of 1 and $2 \mathrm{mg} \mathrm{L}^{-1}$ in the water, after $96 \mathrm{~h}$ of exposure.

These studies show that the median lethal dose and survival of $C$. antennarius compared to other crustacean species may

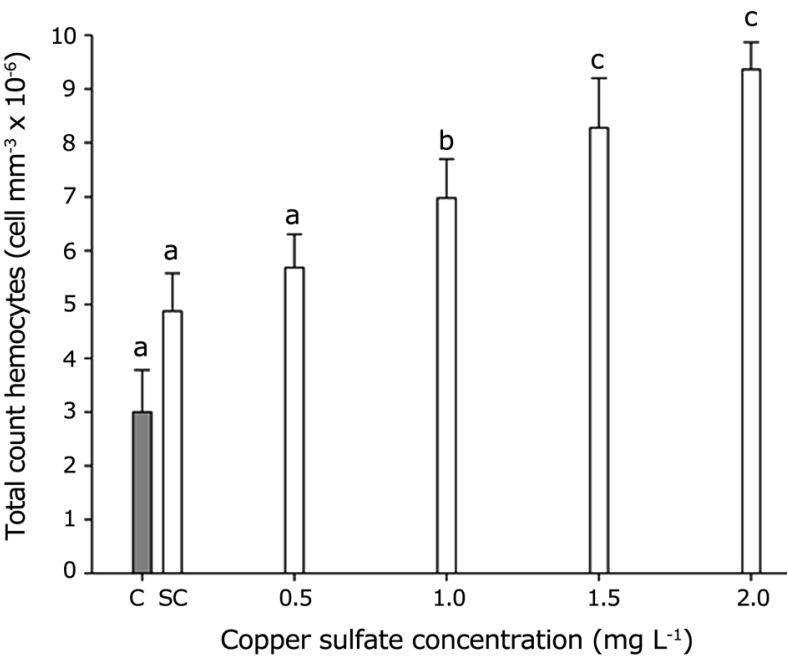

Figure 8. Total hemocyte count (THC cell $\mathrm{mm}^{-3} \times 10^{6}$ ) of Cancer antennarius exposed to different concentrations of copper sulfate. $C$ control, SC saline control. Different letters indicate significant differences between concentrations of copper sulfate ( $\alpha=0.05)$. Media \pm SE / Conteo total de hemocitos (células THC mm$~_{-3} \times 10^{6}$ ) de Cancer antennarius expuesto a diferentes concentraciones de sulfato de cobre. C control, SC control salino. Diferentes letras indican diferencias significativas entre las concentraciones de sulfato de cobre $(\alpha=0,05)$. Media \pm ES

differ due to exposure to this type of metal, as it can be direct (injected into the circulatory system of crustacean) or indirect (the copper dissolved in the seawater). Estuarine and coastal areas are often the most polluted areas in the ocean, due to urban development and human industrial and agricultural activities even though the concentration has a range of 1.5-60 $\mu \mathrm{g} \mathrm{g}^{-1}$. In most of the work when the exposure was indirect the concentrations used were lower $\left(0.05 \mu \mathrm{g} \mathrm{g}^{-1}\right)$ compared to those ones regarding the direct use $\left(1.5 \mathrm{mg} \mathrm{L}^{-1}\right)$ or mixed due of synergetic effects or antagonistic $(\mathrm{Cu} / \mathrm{Zn}$ or $\mathrm{Zn} / \mathrm{Cu}$, FriasEspericueta et al. 2011). In this study, Cancer antennarius had a direct exposure to copper and its median lethal concentration $\left(\mathrm{LD}_{50}\right)$ was in proportion to the volume internal medium (VD) resulting in $1.6 \mathrm{mg} \mathrm{L}^{-1}$.

According to Jones (1941), Cancer antennarius is a strict osmoconformer when it is exposed to different salinities, maintaining an osmolality concentration of $998 \mathrm{mmol} \mathrm{kg}^{-1}$ in their hemolymph. Similar results were found by us in $C$. antennarius from the control group: organisms exposed to higher concentrations of copper had a change in their osmoregulatory pattern from isosmotic to hyperosmotic, a possible damage in the gills, causing disruption of the mechanisms used for the maintenance of water and ions balance in the red 
rocky crab C. anntenarius. In Cancer irroratus and Carcinus maenas, Thumberg et al. (1973), reported a reduction of 90$100 \%$ of their hemolymph osmotic pressure. Bambang et al. (1995) in Penaeus japonicus obtained a change in hypo and hyper-osmoregulatory capacity due to an exposure to a higher copper concentration indicating that an imbalance in plasma ions occurred. The effect of copper on osmoregulatory capacity was therefore dependent on the dose. The mechanism responsible for the variation in crustacean's osmoregulatory capacity seems correlated to the reduction or increasing in ion concentration in the hemolymph and inhibition of the gill $\mathrm{Na}+$ / $\mathrm{K}+$ ATPase activity, however we did not estimate the activity of this pump in the crabs. In the present study, osmoregulatory capacity proved to be a useful tool to monitor the toxic effect of copper, since the osmoregulatory capacity can be used as a physiological marker condition of Cancer antennarius to detect sublethal stress effects and the effect of pollutants in seawater as copper.

Cancer anntenarius oxygen consumption routine rate was affected by the copper concentration used. We observed a direct relationship: as the copper concentration increased, oxygen consumption also increased. Amin \& Comoglio (2010) reported in Lithodes santolla a similar increment in the oxygen consumption routine rate, when organisms were exposed to different copper concentrations. In the fresh water crab Potamonautes warren, when it was exposed to sub lethal effects of copper, the rate of oxygen consumption increased up to the $14^{\text {th }}$ day of exposure (Vosloo et al. 2002). When an organism homeostasis is disturbed, it leads to compensatory adaptive processes that in general, try to compensate the higher energy demand produced by the contaminant, in this case copper. Therefore, the metabolic rate of an organism should increase under toxic stress. Due to the limited energy resources of organisms, the additional metabolic costs result in a reallocation of energy resources (Beyers et al. 1999). Increased of oxygen consumption rate in $C$. antennarius was due to an increase investment of energy to balance the osmoregulatory change.

The ammonium excretion rate was also directly related to the process of osmoregulation since excretion of ammonia by the crabs when exposed to higher copper concentrations increased according to the osmoregulation-impaired ability produced by the stressful conditions. There have been studies on ammonia excretion in crustaceans, as in the case of $P$. chinensis in which Chen \& Lin (1994) found increased levels of ammonia excretion when external medium variations occurred. This is because organisms in diluted media are used to balance their internal medium uptake of sodium by increasing their ammonium excretion through $\mathrm{Na}^{+} / \mathrm{NH}^{+}{ }_{4}$ pump to adjust their osmoregulatory capacity (Spaargaren et al. 1982, Regnault 1987, Jiang et al. 2000).

The O:N atomic ratio in red rocky crab was affected when it was exposed to higher concentrations of copper, reflecting the change of metabolic substrate type. When experimental organisms were exposed to lower concentrations of copper, metabolic energy came from a mixture of lipids and proteins. As for organisms were exposed to higher concentrations of copper, the crabs begin to catabolize proteins as a fuel metabolic substrate. Amin \& Comoglio (2010) reported for Lithodes santolla that when it was exposed to the highest concentration of copper ( $\left.1.61 \mathrm{mg} \mathrm{L}^{-1}\right)$ a $117 \%$ decrease occurred in the rate of $\mathrm{O}: \mathrm{N}$; similar to the results observed in the present study. This change in metabolic substrate was due to the stress to which they were exposed (Mayzaud \& Conover 1988).

In this study, organisms showed an increase of glucose concentration in hemolymph in all copper concentrations tested. Due to stress caused by energy expenditure it derived to a metabolic rate increase in order to obtain energy and to channel the osmoregulation process. Racotta \& Palacios (1998) demonstrated that glucose in the hemolymph of $L$. vannamei increases in response to stress caused by sampling hemolymph.

As for the group or organisms in control (C) and those in saline control (CS) of $C$. antennarius, THC was observed with an interval of $3 \pm 0.78$ to $4.87 \pm 0.74 \times 10^{6}$ in studies conducted with Carcinus aestuarii. Matozzo \& Marin (2010) obtained in the control organisms a THC with a range of 1.04to $12.21 \times 10^{6}$ cell mL $\mathrm{m}^{-1}$ and an average of $6.4 \times 10^{6}$ cells $\mathrm{mL}^{-}$ ${ }^{1}$, which were close to those obtained in this study for the controlled organisms. Truscott \& White (1990) reported that Carcinus maenas had concentrations of 14 to $32 \times 10^{7}$ for crab hemocyte. Smith \& Ratcliffe (1978) obtained similar values of $25 \times 10^{7}$ and $16 \times 10^{7}$ for the same species. THC concentrations are higher because these organisms were exposed to different tidal rhythms. In C. antennarius we observed an increase in the total hemocyte count in relation to the concentration of copper sulfate. This could be due to the fact that crabs defense mechanism has no specificity. Organisms reacted to the copper injection as if it were a foreign agent, but since hemocytes did not find any bacteria, hemocytes did not attack; therefore when hemocytes were counted, the number increased directly proportional to the amount of copper.

Copper is a necessary component to hemocyanin, but excessive amounts lead to crustacean death (Raymont \& Shields 1962, Eisler et al. 1972). In this study, as copper increased, hemocyanin also did in the hemolymph of the crabs. There was a direct correlation between the increase of oxygen consumption rate and the concentration of hemocyanin. That is because this 
protein transports oxygen and in order to increase it requires a greater demand of hemocyanin. Pascual et al. (2003) mention that hemocyanin is a multifunctional protein that can be used as a storage protein, oxygen carrier and osmolytes.

The physiological, metabolic and hematological responses determined in C. antennarius allowed us to quantify the effect of the injection of different concentrations of copper, causing modifications of the physiological steady state of crabs and stress caused by exposure to the pollutant, increasing susceptibility to pathogens.

\section{LITERATURE CITED}

Abolude DS. 2009. Level of heavy metals in freshwater crab (Cardisoma guahumi). International Journal of Animal Veterinary Advances 1: 54-58.

Altinok I \& JM Grizzle. 2003. Effects of low salinities on oxygen consumption of selected euryhaline and stenohaline freshwater fish. Journal of World Aquaculture Society 34: 113-117.

Amin O \& LA Comoglio. 2010. Effects of copper on the physiological responses of the commercial crab Lithodes santolla (Decapoda: Anomura) larvae. Scientia Marina 74: 215-221.

Bambang Y, P Thuet, M Charmantier-Daures, JP Trilles \& G Charmantier. 1995. Effect of copper on survival and osmoregulation of various developmental stages of the shrimp Penaeus japonicus, Bates (Crustacea, Decapoda). Aquatic Toxicology 33: 125-139.

Barata C, I Varo, JC Navarro, A Solayan \& P Cinta. 2005. Antioxidant enzyme activities and lipid peroxidation in the freshwater cladoceran Daphnia magna exposed to redox cycling compounds. Comparative Biochemistry and Physiology C 140: 175-186.

Beyers DW, JA Rice, WH Clements \& CJ Henry. 1999. Estimating physiological cost of chemical exposure: integrating energetics and stress to quantify toxic effects in fish. Canadian Journal of Fisheries and Aquatic Science 56: 814-822.

Boitel F \& JP Truchot. 1989. Effects of sublethal and lethal copper levels on hemolymph acid-base balance and ion concentrations in the shore crab Carcinus maenas kept in undiluted sea water. Marine Biology 103: 495-501.

Brougher D S, LW Douglass \& JH Soares. 2005. Comparative oxygen consumption and metabolism of striped bass Morone saxatilis and its hybrid $M$. chrysops $\mathrm{f} \times M$. saxatilis $\mathrm{m}$. Journal of the World Aquaculture Society 36: 521-529.

Buck KN, JRM Ross, AR Flegal \& KW Bruland. 2007. A review of total dissolved copper and its chemical speciation in San Francisco Bay, California. Environmental Research 105: 9-15.

Carroll J \& R Winn. 1989. Species profiles: life histories and environmental requirements of coastal fishes and invertebrates (Pacific Southwest) brown rock crab, red rock crab, and yellow rock crab. US. Fisheries and Wildlife Services, Biological Report 82: 1-16. [U.S. Army Corps of Engineers, TR EL-82-4]
Cerezo-Valverde J, MD Hernandez, F Aguado-Giménez \& B García-García. 2009. Oxygen consumption in spider crab Maja brachydactyla: effect of weight, temperature, sex feeding and daily light-dark cycle. Aquaculture 298: 131-138.

Chen JC \& JL Lin. 1994. Responses of osmotic and chloride concentrations of Penaeus chinensis Osbeck subadults acclimated to different salinity and temperature levels. Journal of Experimental Marine Biology and Ecology 179: 267-278.

Depledge MM \& PS Rainbow. 1990. Models of regulation and accumulation of trace metals in marine invertebrates. Comparative Biochemistry and Physiology C 97: 1-7.

Eisler R, GE Zarrogian \& RJ Hennekey. 1972. Cadmium uptake by marine organisms. Journal of Fisheries Research and Board of Canada 29: 1367-1369.

Engel DW. 1993. Metal regulation and molting in the blue crab, Callinectes sapidus: copper, zinc, and metallothionein. The Biological Bulletin 172: 69-82.

Engel DW \& M Brouwer. 1987. Metal regulation and molting in the blue crab, Callinectes sapidus: metallothionein function in metal metabolism. The Biological Bulletin 173:237-249.

Frias-Espericueta MG, M Aguilar-Juarez, J Osuna Lopez, S Abad-Rosales, G Izaguirre-Fierro \& D Voltolina. 2011. Los metales y la camaronicultura en México. Hidrobiológica 21(3): 217-228.

Gutierrez-Galindo E, G Flores-Muñoz, V Ortega-Lara \& J Villaescusa-Celaya. 1994. Heavy metals in coastal sediments of the Baja California (Mexico)-California (USA) border zone. Ciencias Marinas 20: 105-124.

Gutierrez-Galindo E, J Villaescusa-Celaya \& G FloresMuñoz. 1997. Heavy metals in geochemical fractions of sediments from the border region of Baja California, Mexico and California, USA. Ciencias Marinas 23: 43-70.

Hagerman L. 1986. Hemocyanin concentration on Crangon crangon after exposure to hypoxia. Comparative Biochemistry and Physiology A 85: 721-724.

Hebel DK, MB Jones \& MH Depledge. 1997. Responses the crustaceans to contaminants exposure: a holistic approach. Estuarine Coastal Shelf and Science 44: 177-184.

Jiang DH, LA Lawrence, WH Neill \& H Gong. 2000. Effect of temperature and salinity on nitrogenous excretion by Litopenaeus vannamei juveniles. Journal of Experimental Marine Biology and Ecology 253: 193-209.

Jones LL. 1941. Osmotic regulation in several crabs of the Pacific Coast of North America. Journal of Cellular Comparative Physiology 18: 79-92.

Lignot JH, C Spanings-Pierrot \& G Charmantier. 2000. Osmoregulatory capacity as a tool in monitoring the physiological condition and the effect of stress in crustaceans. Aquaculture 19:209-245.

MacGinitie GA. 1935. Ecological aspects of a California marine estuary. The American Midland Naturalist 16: 629-765.

Mantel LH \& LL Farmer. 1983. Osmotic and ionic regulation In: Bliss DE \& LH Mantel (eds). The biology of Crustacea. Internal Anatomy and Physiological Regulation 5: 53-161. Academic Press, New York.

Manush SM, AK Pal, N Chatterjee, T Das \& SC Mukherjee. 2004. Thermal tolerance and oxygen consumption of Macrobrachium rosenbergii acclimated to three temperatures. Journal of Thermal Biology 29: 15-19. 
Martins CM, G Barcarolli, IF Menezes, EJ Giacomin, MM Wood \& CM Bianchini. 2011. Acute toxicity, accumulation and tissue distribution of copper in the blue crab Callinectes sapidus acclimated to different salinities: In vivo and in vitro studies. Aquatic Toxicology 101: 88-99.

Matozzo V \& MG Marin. 2010. The role of hemocytes from the crab Carcinus aestuarii (Crustacea, Decapoda) in immune responses: A first survey. Fish and Shellfish Immunology 284: 534-541.

Mayzaud P \& RJ Conover. 1988. O:N ratio as a tool to describe zooplankton metabolism. Marine Ecology Progress Series 45: 289-302.

Mendoza-Rodriguez R. 2010. Acute toxicity of copper sulfate on postlarvae of freshwater prawn Cryphiops caementarius. Archivos de Zootecnia 58: 103-110.

Niencheski LF, HB Baraj, HL Windom \& RG França. 2006. Natural background assessment and its anthropogenic contamination of $\mathrm{Cd}, \mathrm{Pb}, \mathrm{Cu}, \mathrm{Cr}, \mathrm{Zn}, \mathrm{Al}$ and $\mathrm{Fe}$ in the sediments of the Southern Area of Patos Lagoon. Journal of Coastal Research 39 SI: 1040-1043.

Padilla-Ramírez S, F Diaz, AD Re, CE Galindo-Sánchez, AL Sanchez-Lizarraga, LA Nuñez-Moreno, D MorenoSierra, K Paschke \& C Rosas. 2015. The effects of thermal acclimation on the behavior, thermal tolerance and respiratory metabolism in a crab inhabiting a wide range of thermal habitats (Cancer antennarius Stimpson. 1856, the red shore crab). Marine Freshwater Behaviour \& Physiology 54: 133-138.

Pascual C, G Gaxiola \& C Rosas. 2003. Blood metabolites and hemocyanin of the white shrimp Litopenaeus vannamei: the effect of culture conditions and a comparison with other crustacean species. Marine Biology 142: 735-745.

Péqueux A. 1995. Osmotic regulation in crustaceans. Journal of Crustacean Biology 15: 1-60.

Racotta IS \& E Palacios. 1998. Hemolymph metabolic variables in response to experimental manipulation stress and serotonin injection in Penaeus vannamei. Journal of the World Aquaculture Society 29: 351-356.

Raymont JE \& GJ Shields. 1962. Toxicity of copper and chromium in the marine environment. In: Parson EA (ed). Advances in Water Pollution Research. Proceedings of the International Conference, London 3: 275-290. The Macmillan Company, New York.

Re AD \& FL Bückle. 1983. Estudio preliminar de la alimentación en las larvas de Cancer antennarius (Crustacea:Brachiura) en condiciones controladas Ciencias Marinas 9: 77-97.

Regnault M. 1987. Nitrogen excretion in marine and freshwater crustacean. Biological Reviews 62: 1-24.
Santore RC, DM Di Toro, PR Paquin, HE Allen \& JS Meyers. 2001. Biotic ligand model of the acute toxicity of metals. 2. Application to acute copper toxicity in freshwater fish and Daphnia. Environmental Toxicology and Chemistry 20: 2397-2402.

Scelzo MA. 1997. Toxicidad del cobre en larvas nauplii del camarón comercial Artemesia longinaris Bate (Crustacea, Decapoda, Penaeidae). Investigaciones Marinas, Valparaíso 25: 177-185.

Smith VJ \& NA Ratcliffe. 1978. Host defense reactions of the shore crab, Carcinus maenas (L.), in vitro. Journal of Marine Biological Association of the United Kingdom 58: 367-379.

Sokolova IM \& G Lannig. 2008. Interactive effects of metal pollution and temperature on metabolism in aquatic ectotherms: implications of global climate change. Climate Research 37: 181-201.

Spaargaren DH, P Richard \& HJ Ceccaldi. 1982. Excretion of nitrogenous products by Penaeus japonicus in relation to environmental osmotic conditions. Comparative Biochemistry and Physiology A 72: 673-678.

Stohs SJ \& D Bagchi. 1994. Oxidative Mechanisms in the toxicity of metal ions. Free Radical Biology and Medicine 18:321-336.

Thurberg FP, MA Dawson \& RS Collier. 1973. Effects of Copper and Cadmium on osmoregulation and oxygen consumption in two species of estuarine crabs. Marine Biology 23: 171-175.

Truscott R \& NK White. 1990. The influence of metal and temperature stress on the immune system of crabs. Functional Ecology 4: 455-461.

Vargas-Albores F, MA Guzmán \& JL Ochoa. 1993. An anticoagulant solution for haemolymph collection and prophenoloxidase studies of penaeid shrimp (Penaeus californiensis). Comparative Biochemistry and Physiology A 106:299-303.

Vosloo A, WJ Aardt \& LJ Mienie. 2002. Sublethal effects of copper under freshwater crab Potamonautes warren. Comparative Biochemistry and Physiology A 133: 695-702.

Wedderburn J, V Cheung, S Bamber, M Bloxham \& MH Depledge. 1998. Biomarkers of biochemical and cellular stress in Carcinus maenas: an in situ field study. Marine Environmental Research 46: 1-5.

Zheng Z, C Jin, M Li, P Bai \& S Dong. 2008. Effects of temperature and salinity on oxygen consumption and ammonia excretion of juvenile miiuy croaker, Miichthys miiuy (Basilewsky). Aquaculture International 16: 581-589. 